\title{
MEASURING DISPLACEMENTS IN ENGINEERING STRUCTURES BY MEANS OF A COORDINATE LASER STATION
}

\author{
Jacek SZTUBECKI ${ }^{1}$, Adam BUJARKIEWICZ, Małgorzata SZTUBECKA \\ University of Technology and Life Sciences in Bydgoszcz, Bydgoszcz, Poland
}

\begin{abstract}
The application of geodetic methods to examine structures consists in the determination of their displacements relative to an established geodetic reference datum or in the definition of the geometry of their individual components. Such examinations form a picture of changes happening between specific points in time. Modern measurement technologies used in geodetic engineering enable undertaking more and more challenging measurements with increasing accuracy. The purpose of this article is to present a measurement technique involving a Leica TDRA 6000 total station to measure displacements in engineering structures. The station features a direct drive technology to achieve an accuracy of $0.25 \mathrm{~mm}$ in 3-dimensional measurements. Supported by appropriate software, the unit makes a perfect instrument for the monitoring of civil engineering structures. The article presents the results of measurement of static and dynamic displacements in a few engineering structures. The measurements were carried out both in laboratory conditions and on actual, operated civil engineering structures.
\end{abstract}

Keywords: displacement measurement, dynamic response of bridge structures

\section{INTRODUCTION}

Steel is a building material with good mechanical properties, such as durability, elasticity and ductility. Using appropriate cross sections, it is possible to make

\footnotetext{
${ }^{1}$ Corresponding authors: University of Technology and Life Sciences in Bydgoszcz, Faculty of Civil and Environmental Engineering and Architecture, Al. Prof. S. Kaliskiego 7, 85-796 Bydgoszcz, Poland, +48523749942, e-mail: jaceksz@utp.edu.pl, adamb@utp.edu.pl, sztubecka@utp.edu.pl
} 
light structures with long spans [10]. Engineering structures, and those made of steel in particular, undergo changes in geometry over their lifetime. Studies of their movements and vibrations are recommended for operational safety reasons $[8,9]$.

Displacements and deformations of structural components can be examined using precise laser devices. Today, laser technology is omnipresent in industrial metrology applications $[6,11]$. It guarantees a high degree of precision, reaching $+/-15 \mu \mathrm{m}+6 \mu \mathrm{m} / \mathrm{m}$ using a retroreflector, and the operating range of up to 120 $\mathrm{m}[2,5]$. Such parameters are achieved for medium-size civil engineering structures.

One of the fundamental tests involves measurements of the degree of deflection of structural components under load. Some methods used in this type of tests include the following:

- Precise levelling - measurements are performed at selected points of a structure to determine their displacement,

- Microwave deflection measurements, whose advantage consists in the possibility to perform measurements without direct access to the target object,

- Measurements using dial gauges, electronic rulers or proprietary solutions, for example, an instrument for the measurement of displacement of structural elements under static and dynamic loads, using an incremental encoder counting pulses corresponding to the movement of a measuring wheel $[3,4,7]$.

The development of measurement technologies has had a positive influence on the achieved accuracy of geoengineering and surveying measurements. An example of an instrument of improved accuracy can be the coordinate laser station manufactured by Leica, TDRA 6000 (Fig. 1).

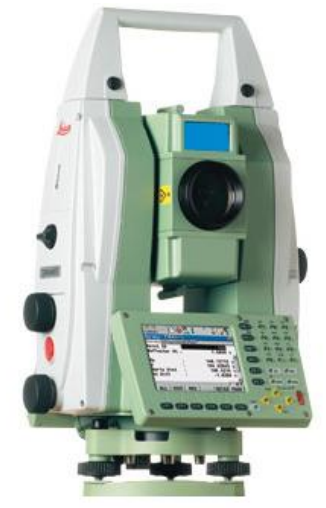

Fig. 1. Leica TDRA 6000 coordinate laser station [12] 
The main features which distinguish TDRA 6000 include:

- Certified distance measurement with a standard error of $\pm 0.1 \mathrm{~mm}$,

- Certified vertical and horizontal measurement with a standard error of $1.3^{\mathrm{c}}$ (0.42"),

- Tracking mode using automatic target recognition and reflector tracking,

- Recording of measured data with a frequency of $5 \mathrm{~Hz}$.

In this article, this type of laser station was used to determine displacements and deformations in engineering structures.

\section{LAB TESTS}

Static and dynamic deflection measurements of a steel beam

In order to determine the possibility of application of a laser station to structural testing, a test model comprising a simple beam with a length of $1 \mathrm{~m}$ was prepared (see Fig. 2).

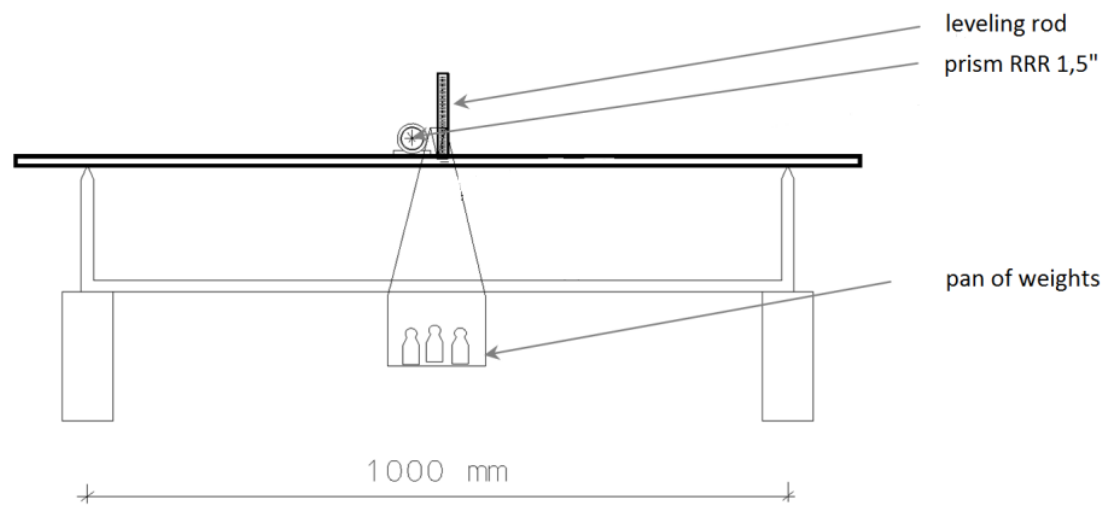

Fig. 2. Drawing of the test model [own elaboration]

The tests involved measurement of the displacement of the centre point of the beam under static and dynamic loads.

In the static test, the measurements of deflection were taken while the beam was loaded and unloaded with $12 \mathrm{~kg}$ of weights on a pan. The measurements were carried out using two methods:

- Precise levelling with an Ni 007 automatic precision level,

- Trigonometric method, using precision measurement by means of the Leica TDRA 6000 laser station.

The static deflection measurement was performed from two sites located $5 \mathrm{~m}$ and $20 \mathrm{~m}$ away from the test model.

In the dynamic test, the measurement of deflection were taken while steadily filling a 121 vessel suspended instead of the pan of weights. The filling process 
was synchronised with measurement carried out by means of the TDRA 6000 station in the tracking mode. The dynamic deflection measurement was taken from a distance of $5 \mathrm{~m}$ and $40 \mathrm{~m}$ from the test model.

In both measurements, the sight line of the TDRA 6000 station was more or less horizontal. During the measurements, the centre point of the beam was observed to change its position.

In the static tests, the results were the readings obtained from a precision levelling rod by means of the $\mathrm{Ni} 007$ automatic level and the spatial coordinates determined using the TDRA 6000 laser station. On their basis, the values of vertical displacement between subsequent states of the loaded/unloaded beam were calculated. The results are shown in Table 1 and Diagrams 1 and 2 below.

Table 1. Summary of the results of beam deflection measured by means of the TDRA 6000 tachymeter and the Ni 007 precision level

\begin{tabular}{|c|c|c|c|c|c|c|c|}
\hline \multirow{2}{*}{ No. } & \multirow{2}{*}{ Weight } & \multicolumn{3}{|c|}{ Deflection - distance 5 m } & \multicolumn{3}{c|}{ Deflection - distance 20 m } \\
\cline { 2 - 8 } & {$[\mathrm{kg}]$} & {$[\mathrm{mm}]$} & {$[\mathrm{mm}]$} & {$[\mathrm{mm}]$} & {$[\mathrm{mm}]$} & {$[\mathrm{mm}]$} & {$[\mathrm{mm}]$} \\
\hline 1 & 0 & 0.00 & 0.00 & 0.00 & 0.00 & 0.00 & 0.00 \\
\hline 2 & 2 & -0.25 & -0.19 & -0.06 & -0.28 & -0.22 & -0.07 \\
\hline 3 & 4 & -0.44 & -0.43 & -0.01 & -0.55 & -0.49 & -0.06 \\
\hline 4 & 6 & -0.68 & -0.68 & 0.00 & -0.76 & -0.73 & -0.03 \\
\hline 5 & 8 & -0.91 & -0.90 & -0.01 & -1.05 & -0.99 & -0.06 \\
\hline 6 & 10 & -1.16 & -1.15 & -0.01 & -1.34 & -1.21 & -0.13 \\
\hline 7 & 12 & -1.39 & -1.40 & 0.01 & -1.50 & -1.50 & -0.01 \\
\hline 8 & 10 & -1.14 & -1.14 & -0.01 & -1.30 & -1.26 & -0.05 \\
\hline 9 & 8 & -0.92 & -0.91 & -0.01 & -1.06 & -1.02 & -0.04 \\
\hline 10 & 6 & -0.69 & -0.68 & -0.01 & -0.78 & -0.68 & -0.10 \\
\hline 11 & 4 & -0.47 & -0.44 & -0.03 & -0.58 & -0.53 & -0.06 \\
\hline 12 & 2 & -0.20 & -0.25 & 0.05 & -0.31 & -0.27 & -0.04 \\
\hline 13 & 0 & -0.04 & 0.01 & 0.03 & -0.01 & 0.00 & -0.01 \\
\hline
\end{tabular}

An analysis of the results demonstrated that with the sight line of $5 \mathrm{~m}$ the maximum difference in the deflection obtained using both methods was -0.06 $\mathrm{mm}$, whereas with the sight line of $20 \mathrm{~m}$ it was $-0.13 \mathrm{~mm}$. The maximum differences fall within the accuracy range of the measurements, which indicates that the two methods used for the static test were comparable.

In the case of dynamic loading applied in a continuously increasing manner (up to $12 \mathrm{~kg}$ ), the principal parameters of deviation of the measured values from the expected values were determined. The linear regression function was used to analyse the results of the dynamic loading test. Diagrams 3 and 4 below show the beam deflection and trend lines for measurements taken at a distance of $5 \mathrm{~m}$ and $40 \mathrm{~m}$. 


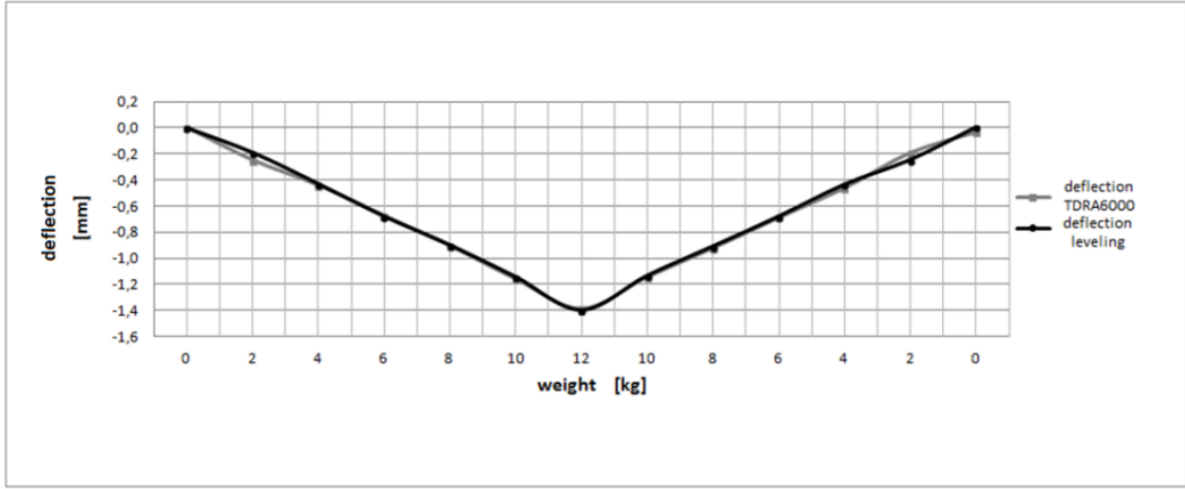

Diagram 1. Beam deflection under static load as measured from a distance of $5 \mathrm{~m}$ [own elaboration]

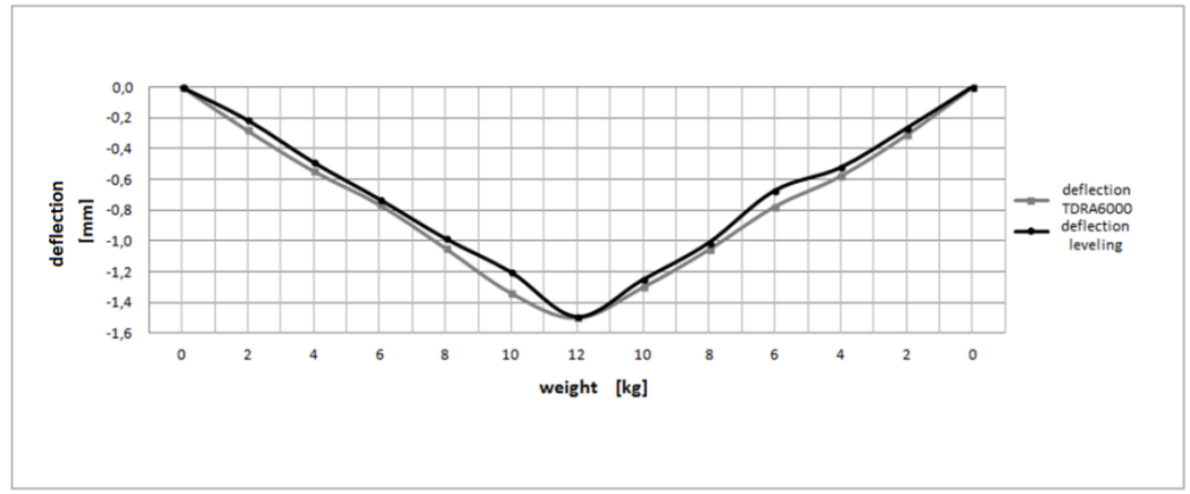

Diagram 2. Beam deflection under static load as measured from a distance of $20 \mathrm{~m}$ [own elaboration]

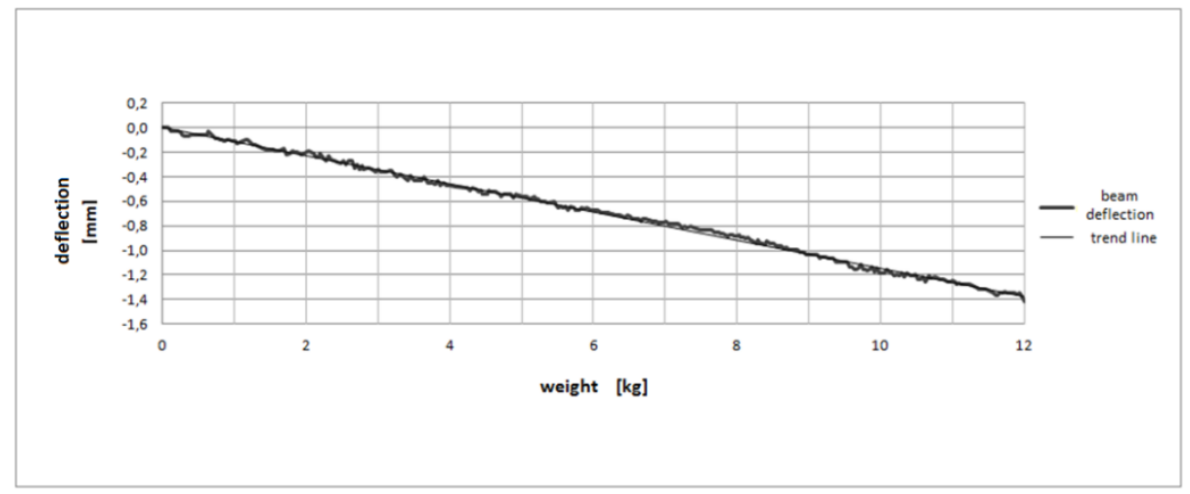

Diagram. 3. Beam deflection and the trend line for the $5 \mathrm{~m}$ distance [own elaboration] 


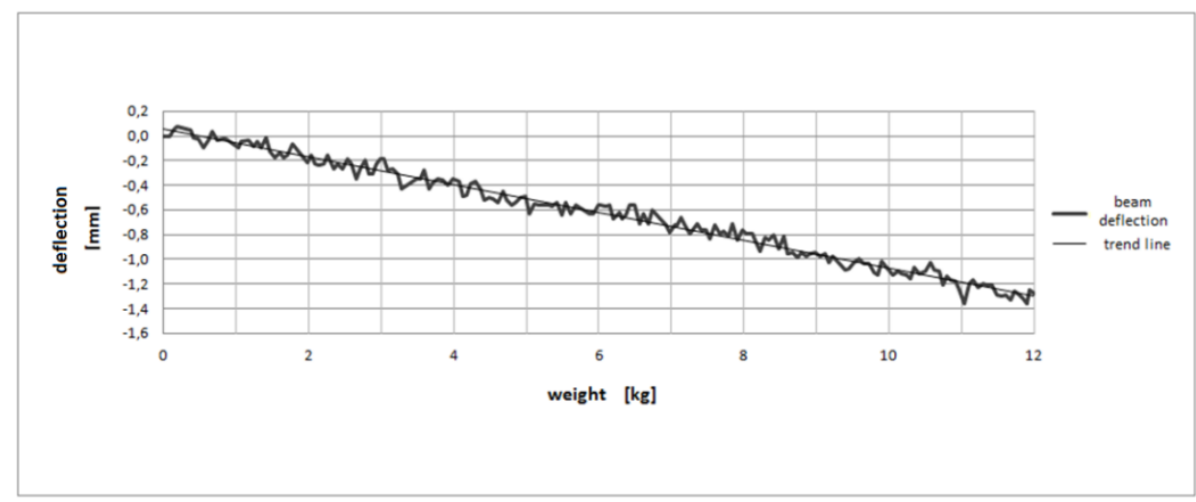

Diagram 4. Beam deflection and the trend line for the $40 \mathrm{~m}$ distance [own elaboration]

The maximum deviation of the measured vertical displacements from the trend line consists in the following ranges:

- For the measurement at the distance of $5 \mathrm{~m}$ : from $-0.05 \mathrm{~mm}$ to $+0.06 \mathrm{~mm}$,

- For the measurement at the distance of $40 \mathrm{~m}$ : from $0.12 \mathrm{~mm}$ to $+0.17 \mathrm{~mm}$.

The standard estimation error in the linear regression was $0.02 \mathrm{~mm}$ and $0.05 \mathrm{~mm}$ for the $5 \mathrm{~mm}$ and the $40 \mathrm{~mm}$ distance, respectively.

A comparison of the deflection values determined in measurements taken $5 \mathrm{~m}$ and $40 \mathrm{~m}$ from the target (Diagram 5) shows that at the greater distance, individual measurements tend to deviate from those obtained at the smaller distance, probably due to disturbances of the laser beam. Nevertheless, the maximum differences between the individual values of deflection measured at both sites did not exceed $0.2 \mathrm{~mm}$.

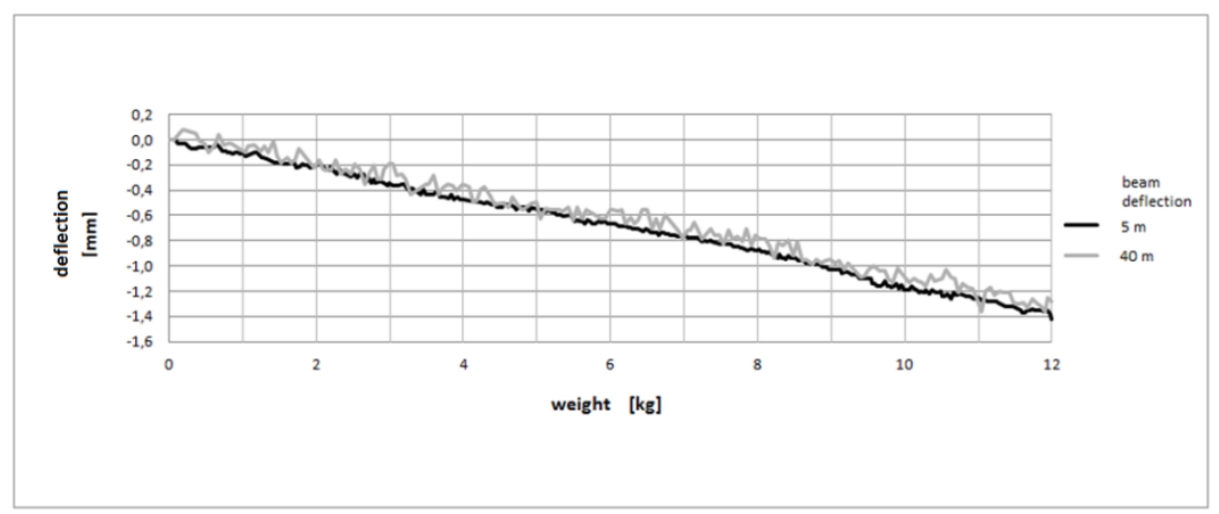

Diagram 5. Comparison of the results of measurements taken at a distance of $5 \mathrm{~m}$ and $40 \mathrm{~m}$ [own elaboration] 


\section{Deformation measurements of a steel structure}

Laboratory tests of a steel structure were performed using a steel space frame of a vehicle, measuring $2.5 \mathrm{~m} \times 2.5 \mathrm{~m} \times 12.0 \mathrm{~m}$, made from welded rectangular hollow sections (Fig. 3.).

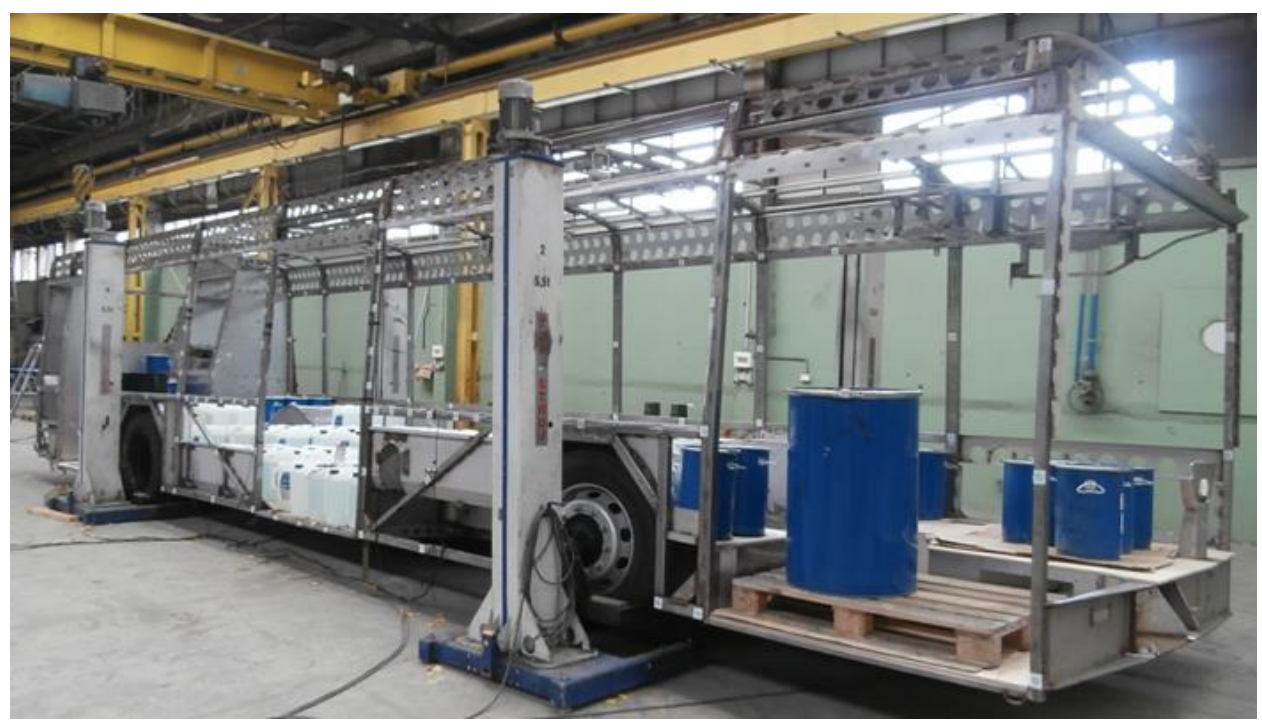

Fig. 3. View of the tested steel structure [1]

The values of displacement under load were determined using the laser station. The tests involved measurements of the geometry and structural state of the steel frame before loading and in a few different loading conditions, which simulated the conditions which can occur in actual operation of the structure. Measurements were taken from a single, permanent site, regularly checked for stability by verifying its reference points by means of a precise red ring reflector, RRR 1.5". In order to facilitate the measurement, appropriate size steel rings were attached to the steel frame to serve as consistent targets for the precise reflector during each series of measurements. Figure 4 shows the arrangement of the measurement points and the supports of the structure.

The laser station was set up at a location allowing measurement of all selected points. In a few areas of the structure (No. 4 and 4), strain gauges were also attached to record tension and to verify that laser station measurements can supplement strain gauge measurements used in diagnostics of civil engineering structures.

The test conditions were designed to reflect real-life operating conditions by fitting wheel sets which were lifted and dropped within a range of $15 \mathrm{~cm}$ during the measurements. The steel structure, weighing $2.5 \mathrm{t}$, was loaded by means of 
weights placed in an uniform manner on the floor frame to provide extra $1.5 \mathrm{t}$ of simulated engine weight, equivalent to a force of $14.7 \mathrm{kN}$, and extra $5.26 \mathrm{t}$ (51.6 $\mathrm{kN}$ ) of payload. The following states were taken into consideration:

A - unloaded structure,

B - structure loaded at the rear (i.e. behind supports No. 3 and No. 4), $14.7 \mathrm{kN}$ (engine weight),

C - structure with uniformly distributed max. payload $(66.3 \mathrm{kN})$,

D - structure with the payload and support No. 1 lifted (at $15 \mathrm{~cm}$ ),

E - structure with the payload and support No. 2 lifted (at $15 \mathrm{~cm}$ ),

F - structure with state A restored.

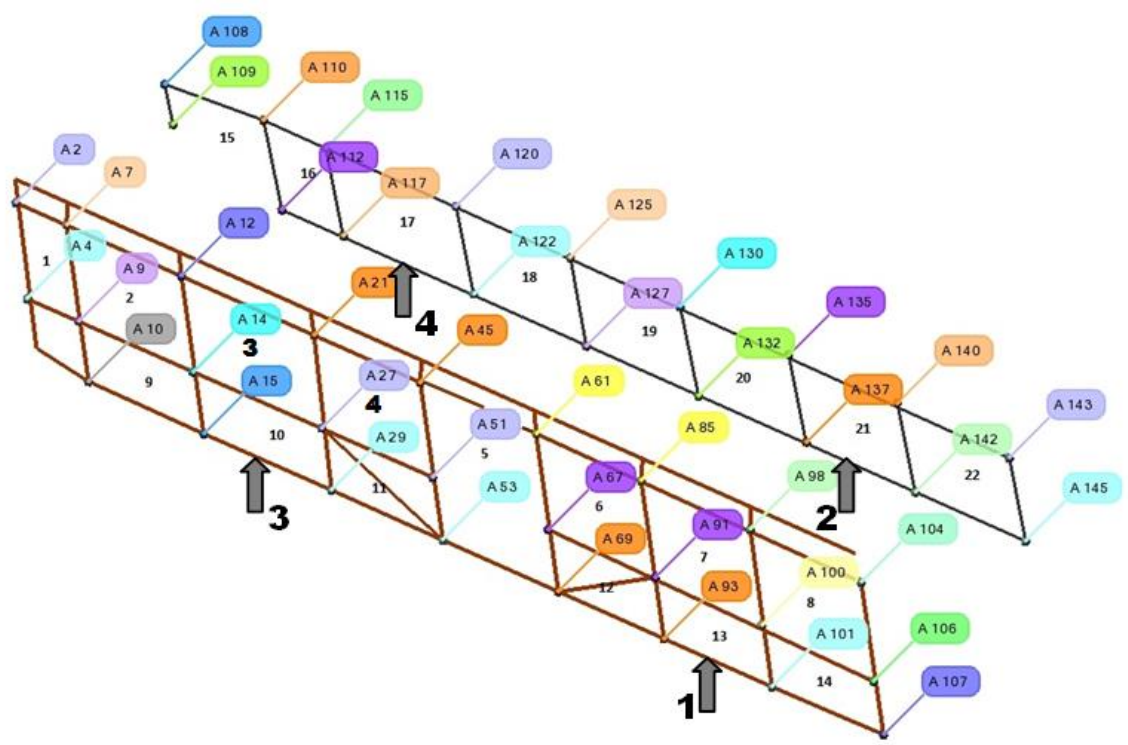

Fig. 4. Arrangement of supports and measurement points [1]

After each change of state of the structure, the subsequent measurement was not performed until its stability was ascertained using the established system of coordinates.

Laser measurements provided the coordinates of the measurement points for all six loading states, in a uniform system. This served as a basis for the determination of distances between adjacent points on the frame and identified their changes due to the variable loading conditions.

The values of the identified changes in the distances for the initial state (A) and the final state $(F)$ of the structure are collected in Table 2. Some structural components were found to have undergone permanent deformation (values in bold, Table 2) when the initial state was restored. The location of the components with changed distances is shown in Figure 5. 
OF A COORDINATE LASER STATION

Table 2. Deformation of structural components in individual areas of the tested frame

\begin{tabular}{|c|c|c|c|c|c|}
\hline \multirow{2}{*}{ Area } & \multirow{2}{*}{\multicolumn{2}{|c|}{ Section }} & \multirow{3}{*}{\begin{tabular}{|l|} 
A state \\
{$[\mathrm{mm}]$} \\
$\mathbf{6 7 7 . 7 9}$ \\
\end{tabular}} & \multirow{3}{*}{$\begin{array}{l}\text { F state } \\
{[\mathrm{mm}]} \\
\mathbf{6 7 8 . 2 5}\end{array}$} & \multirow{3}{*}{\begin{tabular}{|l}
$\begin{array}{l}\text { Difference } \\
{[\mathrm{mm}]}\end{array}$ \\
$\mathbf{0 . 4 6}$ \\
\end{tabular}} \\
\hline & & & & & \\
\hline \multirow[b]{4}{*}{1} & 2 & 7 & & & \\
\hline & 7 & 9 & 1264.99 & 1265.27 & 0.28 \\
\hline & \begin{tabular}{|l|}
9 \\
\end{tabular} & 4 & 683.01 & \begin{tabular}{|l|}
682.99 \\
\end{tabular} & -0.02 \\
\hline & 4 & 2 & 1264.74 & \begin{tabular}{|l|l|}
1264.76 \\
\end{tabular} & 0.02 \\
\hline \multirow[b]{4}{*}{2} & 7 & 12 & 1550.39 & \begin{tabular}{|l|}
1550.57 \\
\end{tabular} & 0.18 \\
\hline & 12 & 14 & 1264.08 & 1264.09 & 0.01 \\
\hline & 14 & 9 & 1542.93 & 1543.17 & 0.24 \\
\hline & 9 & 7 & 1264.99 & 1265.27 & 0.28 \\
\hline \multirow[b]{4}{*}{3} & 12 & 21 & 1782.20 & 1782.10 & -0.10 \\
\hline & 21 & 27 & 1245.01 & 1244.94 & -0.07 \\
\hline & \begin{tabular}{|l|}
27 \\
\end{tabular} & 14 & 1740.54 & \begin{tabular}{|l|}
1740.49 \\
\end{tabular} & -0.06 \\
\hline & 14 & 12 & 1264.08 & \begin{tabular}{|l|}
1264.09 \\
\end{tabular} & 0.01 \\
\hline \multirow[b]{4}{*}{4} & 21 & 45 & 1431.94 & \begin{tabular}{|l|}
1432.47 \\
\end{tabular} & \begin{tabular}{|l|}
0.53 \\
\end{tabular} \\
\hline & 45 & 51 & 1243.26 & \begin{tabular}{|l|}
1244.07 \\
\end{tabular} & \begin{tabular}{|l|}
0.81 \\
\end{tabular} \\
\hline & 51 & 27 & 1490.75 & 1490.79 & 0.04 \\
\hline & 27 & 21 & 1245.01 & 1244.94 & -0.07 \\
\hline \multirow[b]{4}{*}{6} & 61 & 85 & 1411.20 & \begin{tabular}{|l|}
1411.02 \\
\end{tabular} & -0.18 \\
\hline & 85 & 91 & 1257.86 & 1257.90 & 0.04 \\
\hline & 91 & 67 & 1443.96 & \begin{tabular}{|l|}
1443.89 \\
\end{tabular} & -0.07 \\
\hline & \begin{tabular}{|l|}
67 \\
\end{tabular} & 61 & 1264.09 & \begin{tabular}{|l|}
1264.12 \\
\end{tabular} & 0.03 \\
\hline \multirow[b]{4}{*}{7} & 85 & 98 & 1471.40 & 1471.47 & 0.07 \\
\hline & 98 & 100 & 1259.66 & 1259.96 & 0.30 \\
\hline & \begin{tabular}{|l|}
100 \\
\end{tabular} & 91 & 1438.45 & \begin{tabular}{|l|}
1438.62 \\
\end{tabular} & 0.17 \\
\hline & 91 & 85 & 1257.86 & \begin{tabular}{|l|}
1257.90 \\
\end{tabular} & 0.04 \\
\hline \multirow[b]{4}{*}{8} & 98 & 104 & 1494.83 & 1494.83 & 0.01 \\
\hline & \begin{tabular}{|l|}
104 \\
\end{tabular} & 106 & 1299.70 & 1300.95 & 1.25 \\
\hline & 106 & 100 & 1502.84 & 1502.83 & -0.01 \\
\hline & 100 & 98 & 1259.66 & \begin{tabular}{|l|}
1259.96 \\
\end{tabular} & 0.30 \\
\hline \multirow[b]{4}{*}{9} & 14 & 27 & 1740.54 & \begin{tabular}{|l|}
1740.49 \\
\end{tabular} & -0.06 \\
\hline & \begin{tabular}{|l|}
27 \\
\end{tabular} & 29 & 856.50 & \begin{tabular}{|l|}
856.87 \\
\end{tabular} & \begin{tabular}{|l|}
0.37 \\
\end{tabular} \\
\hline & 29 & 15 & 1723.37 & 1723.26 & -0.12 \\
\hline & 15 & 14 & 847.05 & \begin{tabular}{|l|}
847.25 \\
\end{tabular} & 0.20 \\
\hline \multirow[b]{4}{*}{10} & 27 & 51 & 1490.75 & \begin{tabular}{|l|}
1490.79 \\
\end{tabular} & 0.04 \\
\hline & 51 & 53 & \begin{tabular}{|l|}
861.60 \\
\end{tabular} & \begin{tabular}{|l|}
861.19 \\
\end{tabular} & -0.41 \\
\hline & 53 & 29 & 1498.94 & 1499.04 & 0.11 \\
\hline & 29 & 27 & 856.50 & \begin{tabular}{|l|}
856.87 \\
\end{tabular} & \begin{tabular}{|l|}
0.37 \\
\end{tabular} \\
\hline \multirow[b]{4}{*}{11} & 51 & 67 & 1544.99 & 1544.91 & -0.08 \\
\hline & 67 & 69 & 844.64 & 844.96 & 0.32 \\
\hline & \begin{tabular}{|l|}
69 \\
\end{tabular} & 53 & 1554.28 & \begin{tabular}{|l|}
1554.39 \\
\end{tabular} & 0.10 \\
\hline & 53 & 51 & \begin{tabular}{|l|}
861.60 \\
\end{tabular} & \begin{tabular}{|l|}
861.19 \\
\end{tabular} & -0.41 \\
\hline
\end{tabular}




\begin{tabular}{|c|c|c|c|c|c|}
\hline \multirow[b]{4}{*}{12} & $\mid 67$ & 91 & $\mid$\begin{tabular}{|l}
1443.96 \\
$\mid$
\end{tabular} & $\mid$\begin{tabular}{|l}
1443.89 \\
\end{tabular} & $\mid-0.07$ \\
\hline & 91 & 93 & 845.35 & \begin{tabular}{|l|l|}
845.43 \\
\end{tabular} & $\begin{array}{l}0.08 \\
\end{array}$ \\
\hline & 93 & 69 & 1420.82 & \begin{tabular}{|l|l}
1420.76 \\
\end{tabular} & -0.06 \\
\hline & 69 & 67 & 844.64 & 844.96 & 0.32 \\
\hline \multirow[b]{4}{*}{13} & 91 & 100 & 1438.45 & 1438.62 & 0.17 \\
\hline & 100 & 101 & 848.86 & 849.03 & 0.16 \\
\hline & \begin{tabular}{|l|}
101 \\
\end{tabular} & 93 & 1453.29 & 1452.99 & \begin{tabular}{|l|}
-0.30 \\
\end{tabular} \\
\hline & 93 & 91 & 845.35 & 845.43 & 0.08 \\
\hline \multirow[b]{4}{*}{14} & 100 & 106 & 1502.84 & 1502.83 & -0.01 \\
\hline & 106 & 107 & \begin{tabular}{|l}
727.99 \\
\end{tabular} & 726.58 & -1.42 \\
\hline & 107 & 101 & 1516.13 & 1516.45 & 0.32 \\
\hline & 101 & 100 & 848.86 & 849.03 & 0.16 \\
\hline
\end{tabular}

At the same time, strain gauge measurements were carried out for selected components of the steel frame, enabling continuous monitoring of tension during the load tests.

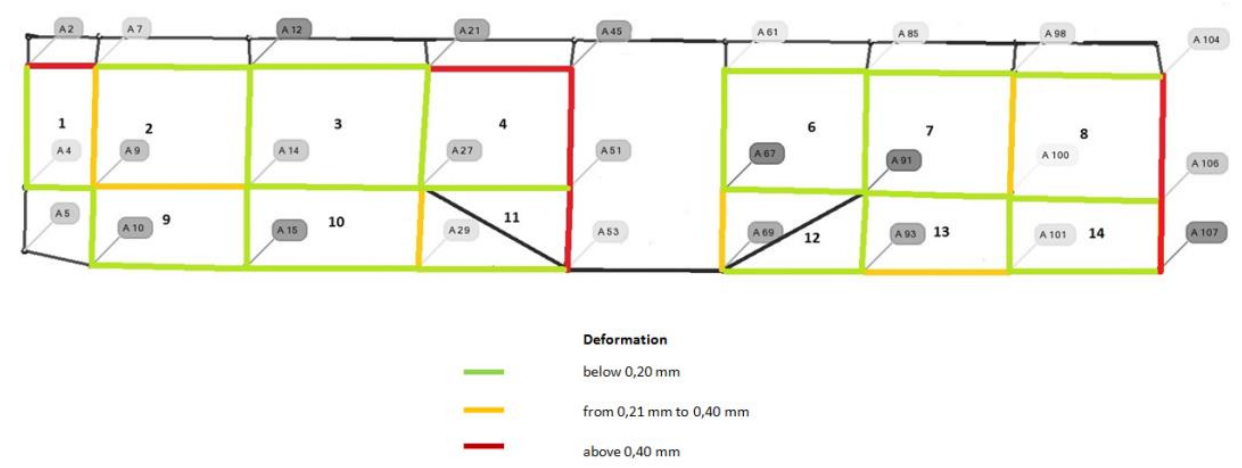

Fig. 5. Location of structural components with changed lengths as a result of test loads [1]

Tension diagrams were recorded for sections No. 21-27 and No. 27-51. Table 3 contains a summary of changes in the length of these sections, whereas Diagrams 6 and 7 show the changing courses of tension.

Table 3. Summary of changes in the length of sections No. 21-27 and No. 27-51

\begin{tabular}{|c|c|c|c|c|c|c|}
\hline \multirow{2}{*}{ Section } & \multicolumn{7}{|c|}{ Distance change [mm] } \\
\cline { 2 - 7 } & A-B & B-C & C-D & D-E & E-F & A-F \\
\hline $\mathbf{2 1 - 2 7}$ & -0.13 & 0.31 & $\mathbf{0 . 3 4}$ & $\mathbf{- 0 . 9 1}$ & 0.33 & -0.07 \\
\hline $\mathbf{2 7 - 5 1}$ & 0.02 & -0.16 & $\mathbf{0 . 1 7}$ & $\mathbf{- 0 . 3 5}$ & 0.36 & 0.04 \\
\hline
\end{tabular}




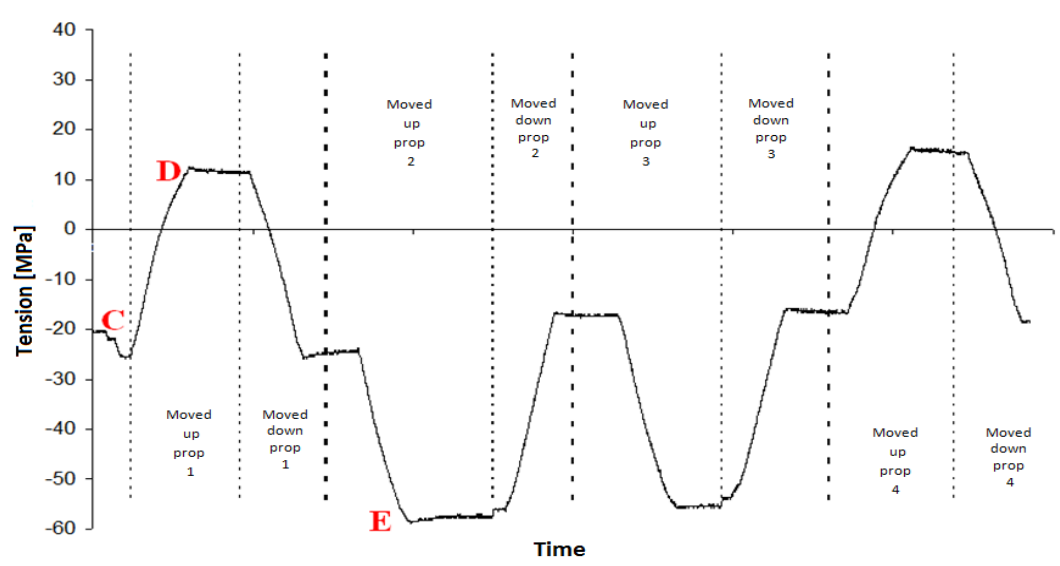

Diagram 6. Tension recorded by the strain gauge attached to section No. 21-27 during loading in C-D and D-E sequences [1]

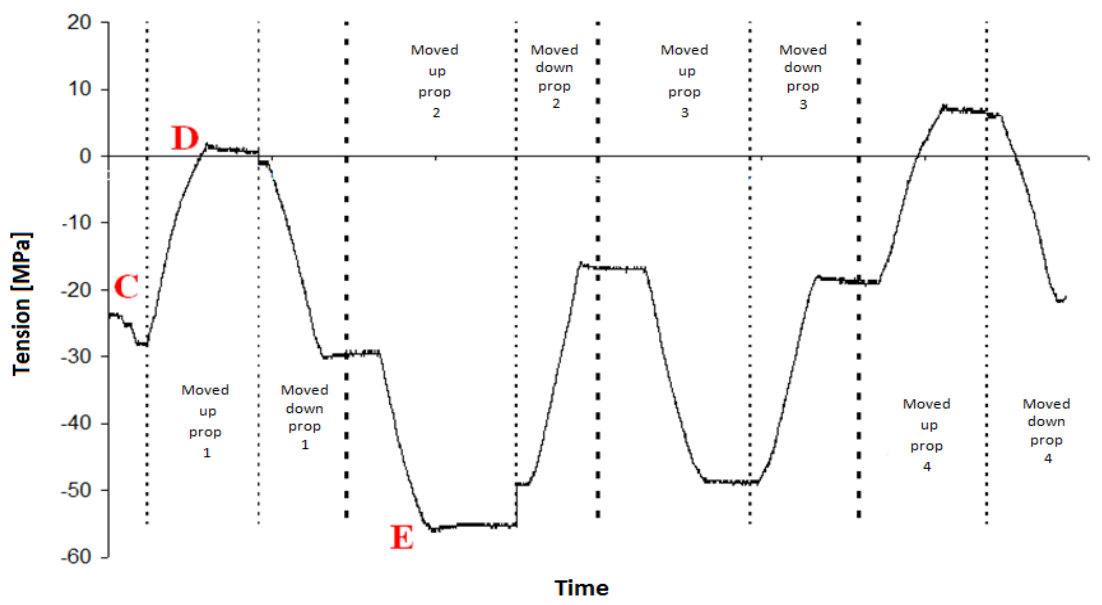

Diagram. 7. Tension recorded by the strain gauge attached to section No. 27-51 during loading in C-D and D-E sequences [1]

Comparing the results of strain gauge measurements (Diagrams 6 and 7) with the results of the changes in the length of beams obtained by means of the laser station (Table 3), a certain correlation can be observed between them. The pattern of the changes in the value of tension recorded by the strain gauges is consistent with the changes in the length found by laser measurement.

\section{FIELD TESTS}

The next step was to verify the results of the lab tests in real-life conditions, using actual engineering structures: a road-rail bridge across the Vistula River in 
Fordon (a district of Bydgoszcz) and a cable-stayed bridge. The latter is a footbridge crossing the Brda River, located near the Luczniczka Sports and Entertainment Arena in Bydgoszcz.

\section{Measurements of span deflection of the road-rail bridge across the Vistula River}

The measurements carried out at the road-rail bridge concerned the deflection of the bottom flange of the bridge span under load from a passing train (Fig. 6).

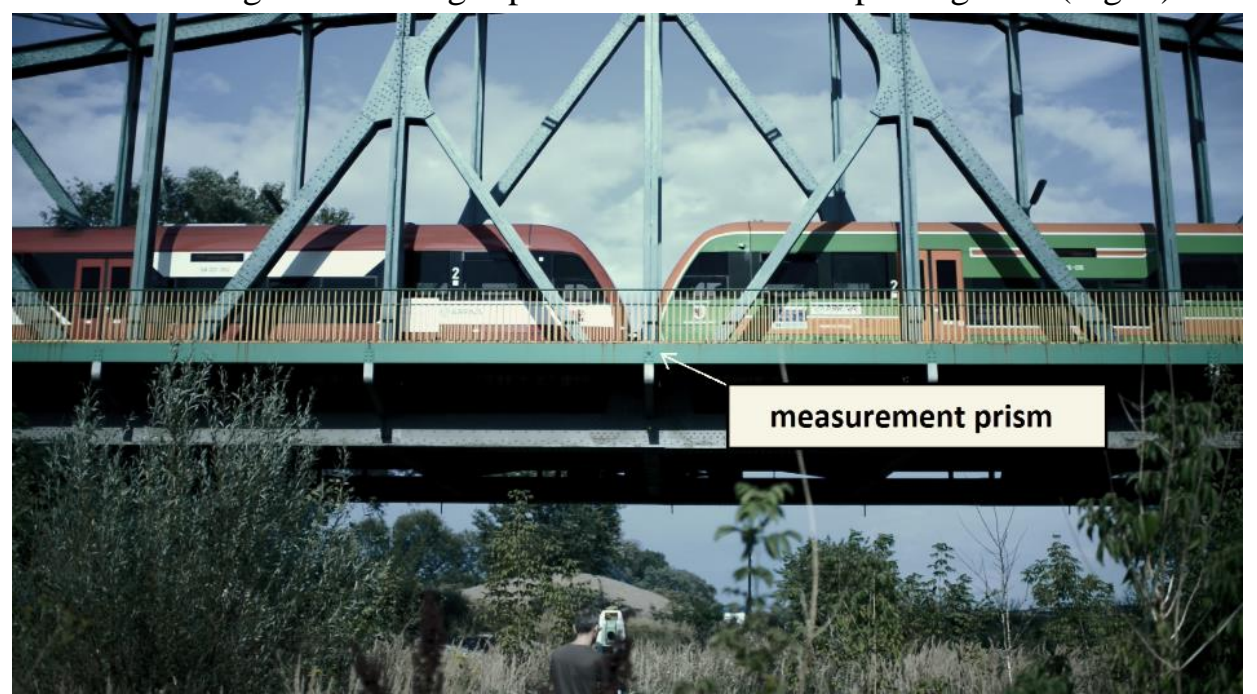

Fig.6. View of the measurement site at the time of crossing by an SA 133 multiple unit [own elaboration]

The prism was placed in the middle of the bridge span, whereas the measurement site was located on firm ground at a distance of approx. $20 \mathrm{~m}$. As it was in the case of the lab tests, prism displacement was recorded in the tracking mode, using the automatic target recognition function and reflector tracking. The vertical displacements of the bridge span were recorded during two crossings of the bridge by a train. The length of the train was $41.7 \mathrm{~m}$, its mass in service was $82 \mathrm{t}$, and the speed while crossing the bridge reached about $60 \mathrm{~km} / \mathrm{h}$. Since the length of the analysed span is $100 \mathrm{~m}$, the recorded deflection was caused by the total weight of the train. The results of deflection measurements taken during the two crossings are shown in Diagrams 8 and 9. 


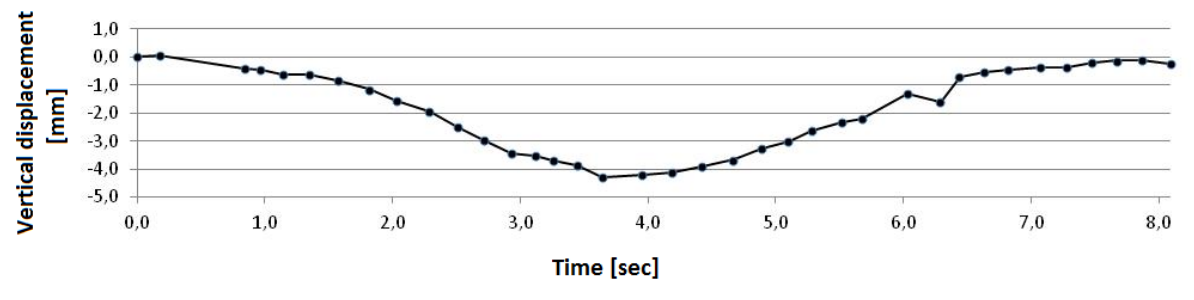

Diagram 8. Bridge span deflection during the first crossing of the bridge [own elaboration]

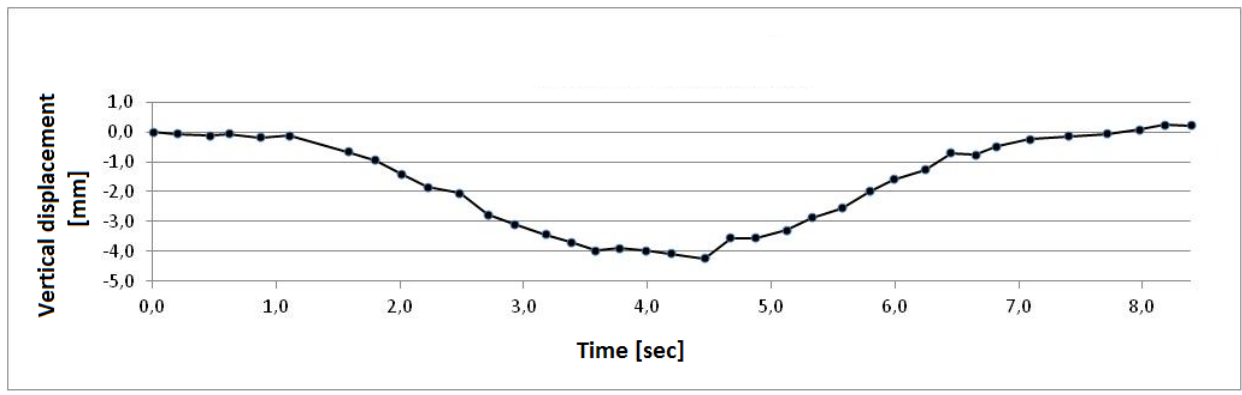

Diagram 9. Bridge span deflection during the second crossing of the bridge [own elaboration]

The results show that the maximum deflection in both cases is similar, reaching $4.30 \mathrm{~mm}$ and $4.23 \mathrm{~mm}$. Comparing the diagrams of deflection over time, the differences between partial deflection values do not exceed $0.51 \mathrm{~mm}$. These differences could have been due to the simultaneous traffic on the parallel road, apart from the error of measurement. Despite these disturbances, the results obtained in both measurements are comparable, and the deflection curves follow a similar pattern.

\section{Measurements of deflection of the cable-stayed bridge across the Brda River}

The cable-stayed bridge has been designed to enable crossing of the river by pedestrians and cyclists. Its total length is $78.00 \mathrm{~m}$, width $4.25 \mathrm{~m}$, and the maximum permissible load is $5 \mathrm{t}$. The footbridge is shown in Figure 7. 


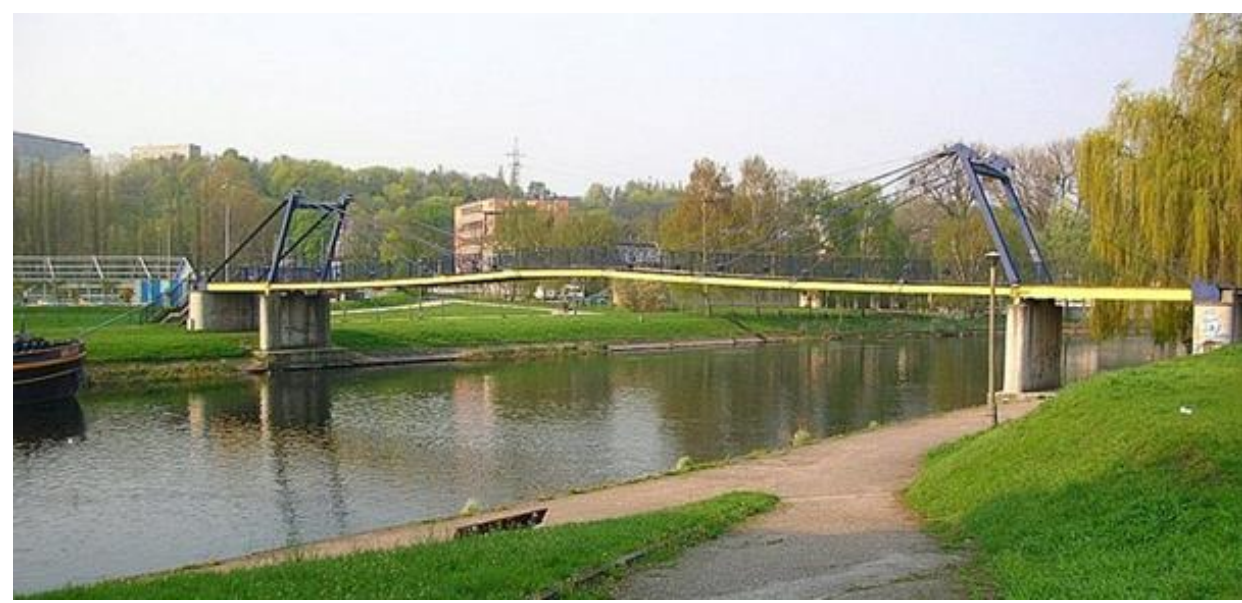

Fig. 7. View of the cable-stayed bridge [own elaboration]

The bridge deflection measurements were carried out when the structure was loaded by a free crossing of a group of people (total weight $1130 \mathrm{~kg}$ ). The deflection diagram is shown below.

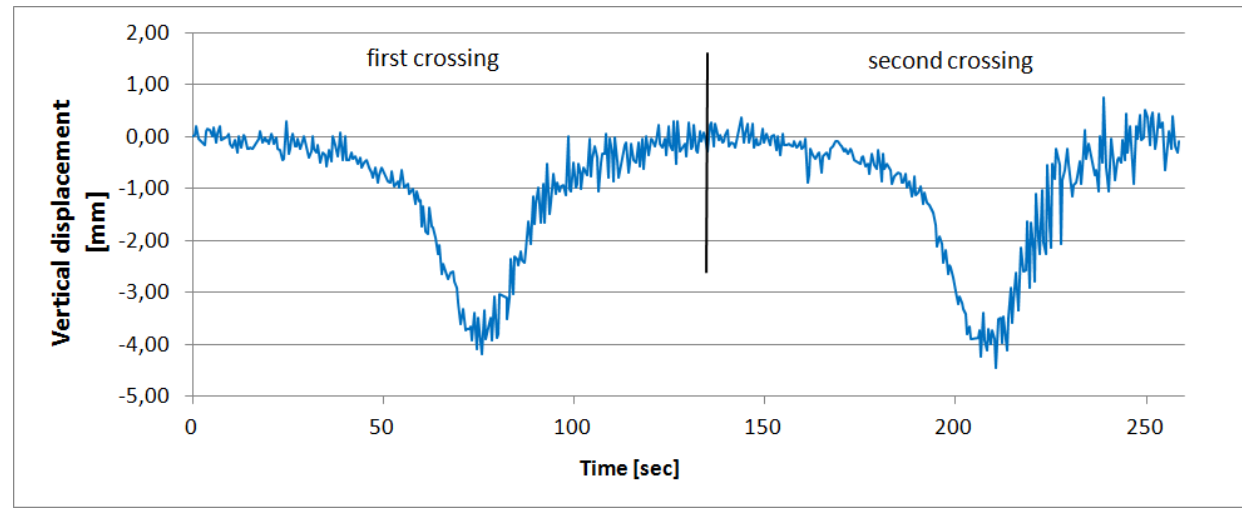

Diagram 10. Deflection of the cable-stayed bridge under the load of a group of passing people [own elaboration]

The diagram presents the results of deflection measured during two crossings of the group in both directions. They indicate that the maximum deflection of the footbridge reached $4.0 \mathrm{~mm}$. The crossing caused vibration, which was reflected in the measurements taken by the laser station.

\section{CONCLUSIONS}

1. The laboratory tests and the field tests both demonstrated that the accuracy of displacement measurements taken by means of the Leica TDRA 6000 
laser station is comparable to the accuracy of measurements performed using the precise levelling method.

2. The possibility of observation of vertical displacements using longer sight lines than allowed in the traditional levelling is a significant advantage of the laser station.

3. While measuring dynamic displacements in the continuous recording mode, the accuracy of measurement was found to decrease with the distance from the target. At a distance of $40 \mathrm{~m}$ from the structure, the deviation from the expected value did not exceed $0.2 \mathrm{~mm}$, which is satisfactory for the required measurement accuracy of the displacement in road engineering structures.

4. The tests of the vehicle frame enabled a quick identification of the areas and extent of its permanent deformations, where further, more detailed diagnostic testing should be performed.

5. The nature of the recorded changes in the value of tension is consistent with the changes in the length found by means of laser measurements, therefore these could supplement strain gauge measurements.

6. The monitoring of structural displacement using a motorised laser station could contribute to a reduction of the time required for measurements and thus - to cost saving. It provides more possibilities of arranging test sites and selecting measurement points, which makes the station a more flexible instrument to evaluate the technical condition of engineering structures.

\section{REFERENCES}

1. Bujarkiewicz A., Sztubecki J., Lis Z.: Badanie odkształceń konstrukcji stalowych w zmiennych warunkach obciążenia z wykorzystaniem laserowej stacji pomiarowej, Konstrukcje betonowe i metalowe, Wydawnictwa Uczelniane UTP, Bydgoszcz 2015.

2. Burge J.H., Peng Su, Chunyu Zhao, Zobrist T.: Use of a commercial laser tracker for optical alignment, Optical System Alignment and Tolerancing, edited by José M. Sasian.

3. Cianciara A.: Dynamiczne monitorowanie mostów techniką mikrofalową, MOSTY 1/2009, 2009.

4. Erdelyi J.: Determination of bridge structure deformation using TLS, Reports on Geodesy z. 1/90 (2011) 115-121.

5. Golparvar-Fard M., Bohn J., Teizer J., Savarese S., Peña-Mora F.: Evaluation of image-based modeling and laser scanning accuracy for emerging automated performance monitoring techniques, Automation in Construction, Volume 20, (2011) 1143-1155.

6. Jakubiec W., Malinowski J.: Metrologia wielkości geometrycznych, Wydawnictwa Naukowo-Techniczne, Warszawa 2004. 
7. Jamka M.: Badania przemieszczeń pionowych konstrukcji pod obciążeniem dynamicznym, Problemy Kolejnictwa Zeszyt 152, (2011) 143-154.

8. Łagoda M.: Diagnostyka i monitoring mostów w Europie, Materiały Budowlane 7/2011 (nr 467), (2011) 36-38.

9. Podhorecki P.: Monitoring, analiza numeryczna oraz ocena przyczyn uszkodzeń i koncepcja naprawy kratownicowego mostu autostradowego w USA, Materiały Budowlane 7/2012 (nr 479), (2012) 4-10.

10. Rykaluk K.: Konstrukcje stalowe. Podstawy i elementy, Dolnośląskie Wydawnictwo Edukacyjne, Wrocław 2009.

11. Wojcik G.J., Lakanen S. A.: Laser Tracker, a handy tool for metrology and alignment. Proceedings of the 7th International Workshops on Accelerator Alignment, SPring-8, Japan, 14 November 2002.

12. www.leica-geosystems.pl

\section{BADANIE PRZEMIESZCZEŃ OBIEKTÓW INŻYNIERSKICH Z WYKORZYSTANIEM STACJI LASEROWEJ}

\section{Streszczenie}

Badania konstrukcji metodami geodezyjnymi polegają na wyznaczeniu jej przemieszczeń względem przyjętego układu odniesienia lub na określeniu geometrii poszczególnych elementów. Dają one obraz zmian pomiędzy przyjętymi momentami czasu. Nowoczesne technologie pomiarowe stosowane w geodezji pozwalają na realizowanie coraz bardziej skomplikowanych zadań pomiarowych oraz uzyskiwanie coraz większych dokładności. Celem artykułu jest przedstawienie technologii pomiaru przemieszczeń konstrukcji inżynierskich $\mathrm{z}$ wykorzystaniem stacji laserowej Leica TDRA 6000. Stacja ta wyposażona jest $\mathrm{w}$ technologię napędu bezpośredniego, pozwalającą na uzyskiwanie dokładności pomiaru 3D na poziomie $0,25 \mathrm{~mm}$. Wraz $\mathrm{z}$ odpowiednim oprogramowaniem jest doskonałym narzędziem umożliwiającym monitorowanie obiektów inżynierskich. Zaprezentowano wyniki pomiarów przemieszczeń statycznych oraz dynamicznych kilku konstrukcji inżynierskich. Pomiary wykonywano zarówno $\mathrm{w}$ warunkach laboratoryjnych jaki na istniejących i eksploatowanych obiektach.

Słowa kluczowe: pomiar przemieszczeń, dynamika konstrukcji mostowych 